Rynnelle Wiebe

School of Library and Information Studies, University of Alberta, Edmonton, AB, Canada

Dinesh Rathi

School of Library and Information Studies, University of Alberta, Edmonton, AB, Canada

\title{
A Review of Library Associations Websites to Learn about Decolonizing Efforts (Paper)
}

\begin{abstract}
:
CFLA-FCAB's Truth and Reconciliation Report and Recommendations (2017) has galvanized Canadian libraries and library associations to undertake initiatives to decolonize libraries. Similar efforts are happening internationally as libraries work toward reconciliation. This paper presents findings of an environmental scan and analysis of library association websites from Canada, the United States, Australia, and New Zealand. The findings demonstrate that library associations are taking a number of initiatives such as providing access to resources, initiating guidelines and policies, hosting events, offering financial support, and other initiatives.
\end{abstract}

\section{Introduction}

The Canadian Federation of Library Associations (CFLA-FCAB) Truth and Reconciliation Committee delivered a Truth and Reconciliation Report and Recommendations in 2017 as part of their mandate to "promote initiatives in all types of libraries to advance reconciliation" (CFLAFCAB 2017, 3). Since the release of the Report, Canadian libraries and library associations have responded to these Recommendations. While this represents a Canadian context, efforts toward decolonizing libraries are present internationally, offering the opportunity to learn from these initiatives. Reviewing library association websites is a useful way to understand how the community in general, represented through these associations, is responding to reconciliation. Library associations share relevant information and resources by and for member libraries and librarians, and establish standards or guidelines and other supports. This paper reviews how library associations from Canada, the United States (US), Australia, and New Zealand demonstrate a commitment to decolonization through publicly shared content on their websites.

\section{Literature Review}

As this paper explores reconciliation and decolonization within the framework of the Canadian Truth and Reconciliation Commission, reconciliation will be understood as defined by the TRC of Canada (2015). According to the Commission, reconciliation is "about establishing and maintaining a mutually respectful relationship between Aboriginal and non-Aboriginal peoples in this country" (p.6), and it "requires that a new vision, based on a commitment to mutual respect, be developed" (p.VI). Decolonization is about "dismantling colonialist power in 
all its forms" (Ashcroft et al. 2001 p.52) and it involves engaging with "imperialism and colonialism at multiple levels" (Smith 2012, p.58).

Library association websites are the subject of this research because of the role associations play in the LIS community. Associations demonstrate how libraries work toward change by setting standards to "[guide] toward the realization of ideals" (Masalinto, Prosperoso, Yap 2015, 2), setting goals, and planning future change (Obille 2007). Further, professional associations encourage actions and diffuse knowledge among members (Newell \& Swan, 1995a), which can shape conversations around complex topics such as reconciliation and decolonization. For example, library associations may develop standards to support member libraries in setting goals or establishing levels of service, such as the ALA's Core Competences as a standard of knowledge for MLIS graduates from ALA-accredited programs (American Library Association 2009). Specifically, associations like CFLA-FCAB through the Committee on Indigenous Matters, for example, are working towards providing guidance and direction to member libraries on moving toward decolonization and reconciliation.

Canadian scholars have discussed the Calls to Action and Report and Recommendations, and argued that it is important to bring change and work toward decolonization (Blair \& Wong 2017; Edwards 2019; Smith 2017). Most of this research focuses on particular efforts or case studies in Canadian academic libraries (Laroque 2018), health libraries (Giustini 2017; Linton \& Ducas 2017; Maestro \& Chadwick 2017), and archives (Bak, Bradford, Loyer, \& Walker 2017). These Canadian studies emphasize the importance of implementing the Calls to Action and share effective initiatives. Internationally, the 1995 Australia Library and Information Association's Aboriginal and Torres Strait Islander Protocols for Libraries, Archives and Information Services (ATSILIRN) has been the subject of various studies (Blackburn 2014; Garwood-Houng \& Blackburn 2014; Janke \& Iacovino 2012; Reyes-Escudero \& Cox 2017; Thorpe \& Byrne 2016; Thorpe \& Galassi 2018). Additionally, Australia's National Policy Framework for Aboriginal and Torres Strait Islander Library Services and Collections provides guidance for both libraries and archives (Blackburn 2014; Janke \& Iacovino 2012). While scholars study the effects of these Protocols and Frameworks, they often focus on libraries and case studies rather than associations.

Chilcott (2019) examines Australian and North American approaches to decolonizing archival language in order to adapt similar strategies in a UK context. Chilcott (2019) reviews Australia's ATSILIRN Protocols, the State Records New South Wales (NSW) Protocols for Staff Working with Indigenous People, the Aboriginal and Torres Strait Islander Data Archive (ATSIDA) Protocols, and the United States' Protocols for Native American Archival Materials. In a similar Canadian study, Maestro and Chadwick (2017) analyze Canadian Health Library websites for responses to TRC Calls to Action.

The above studies do not examine library association content but demonstrate the value of comparing decolonizing efforts both internationally and nationally and suggest that there is limited literature reviewing efforts of associations toward decolonization and reconciliation. As part of the CFLA Report and Recommendations, the Black Team developed a list of Public-Facing Statements, Policies, and Services, identifying efforts toward decolonization in Indigenous community libraries, academic libraries, public libraries, government and special libraries, and associations in Canada and internationally (CFLA-FCAB 2017, 13). This paper does similar work with a focus on library association websites with the purpose of comparison and learning. 


\section{Methodology}

An environmental scan and analysis of library association websites was used in this project. A list of library associations in four countries, the United States (US), Canada, Australia and New Zealand, was compiled using a search engine. The finalized list had ninety-two association websites including associations of General Libraries, Health Libraries, Indigenous or Visible Minority Librarians, Law Libraries, Public Libraries, Research and Academic Libraries, School Libraries, Special Libraries/Librarians, Theological Libraries/Librarians, and Association Federations. The websites were both browsed and searched using relevant terms (e.g., Indigenous, Aboriginal, specific communities like Maori in New Zealand) to identify different types of content present on association websites related to decolonization. Each website's search function was used for this process; websites without a search function were searched using a search engine. Analysing websites through browsing and searching is an "unobtrusive" method that allows for effective qualitative analysis of themes and patterns found on the websites (Luo 2018, 237).

The relevant content identified through browsing and searching was collected and analyzed using thematic analysis (Braun \& Clarke, 2006; Neuendorf, 2019), coding the information into categories. A single (primary) coder mainly completed the review of websites and thematic coding of the content, with an additional reviewer who reviewed both websites as flagged by the primary coder, and thematic categories and their labels as needed. Limitations of this research include the use of website content, which is often updated and changed, and is limited to what is made publicly available (Maestro \& Chadwick 2017), the use of a single coder which has implications on the identification of and categories, and the variation in number and type of associations from each country.

\section{Findings}

An analysis of publicly accessible website content of library associations from the US, Canada, Australia, and New Zealand demonstrates that while library associations in each of these countries engage in decolonizing initiatives, not all websites demonstrated the association's efforts toward decolonization and reconciliation: fifty-one websites of the ninety-two analyzed had relevant content (55.4\%). Additionally, associations use different strategies and share varying levels of content through their websites. For example, Australia and New Zealand library association websites include numerous policies, guidelines, protocols, or statements, but this kind of formal commitment is less evident on the US and Canada associations websites. Interestingly, the US associations tend to have more content from individuals, while Australian and New Zealand associations present content by the association itself and less content from individuals.

\subsection{Types of Initiatives}

After browsing and searching library associations' websites, the collected information was coded by themes, and categories were developed to better understand the types of initiatives discussed. These categories include Special Interest Groups (such as Equity, Diversity, and Inclusion groups), Commitments (including strategic plans), Formal Guidelines and Policies, Resource Lists, Informational Artifacts (such as news or blog posts), Events and Activities (such as conferences), Financial Support (such as scholarships), Training and Mentorship (including workshops and webinars), and Other. This categorization of initiatives present on library associations' websites demonstrates how associations tend to contribute to or promote reconciliation and decolonization 
efforts among their members and for the public, based on the needs and roles of their members within the LIS community.

\subsection{Associations in North America-The United States and Canada}

Fifty library associations from the US were analyzed for their decolonization efforts; twenty-four websites contained decolonization or reconciliation content. Though ACRL (Association of College and Research Libraries) endorses the Protocols for Native American Archival Materials, most of the associations lacked formal statements, standards, or policies relating to decolonizing or reconciliation efforts set by the association. However, some websites have information about special interest groups or subcommittees that focus on Indigenous matters, such as the American Association of Law Libraries' Indigenous Peoples Law Group and Oklahoma Library Association's Tribal Libraries Committee. In the absence of formal commitments or statements, some websites included Indigenous or decolonizing resource lists (e.g., Wisconsin Library Association) or information artifacts such as articles, blog posts, or conference presentations related to decolonization efforts by individual librarians (e.g., ALA; Michigan Library Association; Oklahoma Library Association; Tennessee Library Association; Western Association of Map Libraries). One important association, the American Indian Library Association, is an affiliate of the ALA that focuses on improving library and information services on reserves, and sharing about Indigenous culture and information needs throughout the library community. Overall, most of the US library associations do not present public-facing formal guidelines or policies regarding efforts toward decolonization.

Nineteen Canadian library association websites were reviewed to learn about decolonizing efforts; thirteen demonstrated relevant content. Some associations made direct connections to the TRC's Calls to Action or the CFLA's Report and Recommendations, endorsing the Report (e.g., Library Association of Alberta) or including the report in a list of Indigenous or decolonizing resources (e.g., The Canadian Association for School Libraries; Ontario Library Association). Other associations also provide resource lists for decolonization or Truth and Reconciliation (e.g., CFLA; Ontario Library Association; Library Services for Saskatchewan Aboriginal Peoples Committee; Saskatchewan Library Association). The Ontario Library Association (n.d.) formalizes their commitment to decolonization as a strategic goal to "Support the First Nations" (para. 2.5). Similarly, the Nunavut Library Association (n.d.) includes Indigenous priorities in their Values, committing to providing services and materials in "Inuktut, English and French" (para. 4). Like the US associations, a select few Canadian associations provide information on special interest groups (eg., the Canadian Association of Law Libraries' Diversity, Inclusion, and Decolonization Committee; Ontario Library Association's Indigenous Task Group, and; CFLA's Indigenous Matters Committee), or share information artifact such as articles and posts related to decolonization created by individuals (e.g., Nova Scotia Library Association's interview with Camille Callison about responding to TRC's Calls to Action).

\subsection{Associations in Australasia - Australia and New Zealand}

A total of nine Australian library association websites were reviewed, five of which had content regarding reconciliation and decolonization. The decolonizing content on these associations' websites greatly differs from the North American associations' websites. For example, the Australian Library and Information Association (ALIA) website contains the most information, including Indigenous Matters initiatives, focus, engagement, and updates, as well as the Improving 
Library Services to Aboriginal and Torres Strait Islander Peoples Report. Included in ALIA's guidelines are The Aboriginal and Torres Strait Islander Protocols for Libraries, Archives and Information Services; ALIA's Libraries and Information Services and Indigenous Peoples policy; and the Standards and Guidelines for Australian Public Libraries with Services for Indigenous Australians. Public Libraries Australia also includes resources related to reconciliation efforts such as their Building Indigenous Services \& Collections in Libraries Masterclass. While few Australian associations have decolonizing information, the content differs from many of the North American associations, with reference to numerous formal guidelines, policies, or standards that direct decolonizing efforts in libraries in Australia.

Only two New Zealand library associations were reviewed, and both websites contained relevant information. Like Australian association websites, the content on these websites includes formal guidelines for decolonization. For example, the Library and Information Association of New Zealand Aotearoa (LIANZA) has a formal partnership with Te Rōpū Whakahau, who represent Maori interests and advise LIANZA. LIANZA also has a Maori Subject Headings subcommittee that focuses on decolonization of subject headings. Also, both LIANZA and the School Library Association of New Zealand Aotearoa (SLANZA) have statements regarding library services for Indigenous peoples (e.g., LIANZA's Library and Information Services to Pacific Peoples; SLANZA's Treaty of Waitangi Policy).

The remaining twelve websites were associated with more than one country, often based on geography. Seven websites included North American countries, one website included both Australia and New Zealand, and four websites served multiple countries in various regions, and were categorized as "International" associations.

\section{Conclusion}

The analysis of content related to decolonization and reconciliation on library association websites demonstrates that associations engage with calls to decolonize libraries in different ways. The categorization of the types of content associations publish on their websites allows other library associations and LIS professionals to learn methods of contributing to and promoting reconciliation and decolonization in their spheres of influence. Further investigation is required to identify reasons for differences in efforts among associations based on geography and association type, as well as the implications of these differences for member professionals and institutions. The review of multiple associations' websites from different countries provides an opportunity for us in Canada to learn from other countries' library associations' experiences, efforts and their practices which will help in addressing gaps in our approaches as we work toward reconciliation and decolonization today and tomorrow.

\section{Reference List:}

American Library Association. (2009). Core competences of librarianship. Retrieved from http://www.ala.org/educationcareers/sites/ala.org.educationcareers/files/content/careers/c orecomp/corecompetences/finalcorecompstat09.pdf

Ashcroft, B., Griffiths, G., \& Tiffin, H. (2001). Key concepts in post-colonial studies. London, UK: Routledge. 
Bak, G., Bradford, T., Loyer, J., \& Walker, E. (2017). Four views on archival decolonization inspired by the TRC's Calls to Action. Fonds d'Archives, 1, 1-20. https://doi.org/10.29173/fa3

Blackburn, F. F. B. gov. a. (2014). An Example of Community Engagement: Libraries ACT and the ACT Aboriginal and Torres Strait Islander Communities. Australian Academic \& Research Libraries, 45(2), 121-138. https://doi.org/10.1080/00048623.2014.908497

Blair, J., \& Wong, D. (2017). Moving in the circle: Indigenous solidarity for canadian libraries. Partnership: The Canadian Journal of Library and Information Practice and Research, 12(2), 1-7. https://doi.org/10.21083/partnership.v12i2.3781

Braun, V., Clarke, V. (2006). Using thematic analysis in psychology. Qualitative Research in Psychology, 3(2), 77-101. DOI: 10.1191/1478088706qp063oa

CFLA-FCAB. (2017). Truth and reconciliation committee report and recommendations. Retrieved from http://cfla-fcab.ca/en/indigenous/trc_report/

Chilcott, A. (2019). Towards protocols for describing racially offensive language in UK public archives. Arch Sci, 19(4), 359-376. https://doi.org/10.1007/s10502-019-09314-y

Edwards, A. (2019). Unsettling the Future by Uncovering the Past: Decolonizing Academic Libraries and Librarianship. Partnership: The Canadian Journal of Library \& Information Practice \& Research, 14(1), 1-12. https://doi.org/10.21083/partnership.v14i1.5161

Garwood-Houng, A., \& Blackburn, F. (2014). The ATSILIRN protocols: A twenty-first century guide to appropriate library services for and about aboriginal and torres strait islander peoples. Australian Library Journal, 63(1), 4-15. https://doi.org/10.1080/00049670.2014.890018

Giustini, D. (2017). As Canadian health librarians we must now move ahead on the Truth and Reconciliation (TRC) Calls to Action. Journal of the Canadian Health Libraries Association (JCHLA), 38(3), 118-120. https://doi.org/10.29173/jchla/jabsc.v38i3.29346

Goulding, A., \& Crump, A. (2017). Developing inquiring minds: Public library programming for babies in Aotearoa New Zealand. Public Library Quarterly, 36(1), 26-42. https://doi.org/10.1080/01616846.2017.1275600

Janke, T., \& Iacovino, L. (2012). Keeping cultures alive: archives and Indigenous cultural and intellectual property rights. Archival Science, 12(2), 151-171. https://doi.org/10.1007/s10502-011-9163-0

Laroque, S. (2018). Making meaningful connections and relationships in cataloguing practices: The Decolonizing Description Project at the University of Alberta Libraries. Evidence Based Library and Information Practice, 13(4), 2-6. https://doi.org/10.18438/eblip29440

Linton, J., \& Ducas, A. (2017). A new tool for collection assessment: One library's response to the calls to action issued by canada's truth and reconciliation commission. Collection Management, 42(3-4), 256-279. https://doi.org/10.1080/01462679.2017.1344596

Luo, L. (2018). Health information programming in public libraries: a content analysis. Public Library Quarterly, 37(3), 233-247. https://doi.org/10.1080/01616846.2018.1498704

Maestro, L., \& Chadwick, D. (2017). Canadian health libraries' responses to the Truth and Reconciliation Commission's Calls to Action: A literature review and content analysis. 
Journal of the Canadian Health Libraries Association (JCHLA), 38(3), 92-101. https://doi.org/10.29173/jchla/jabsc.v38i3.29300

Masalinto, M. L. D., Prosperoso, A. M. D., \& Yap, J. M. (2015). Embedding standards for medical and health libraries in the Philippines: Identifying challenges and opportunities. Journal of Philippine Librarianship, 35, 1-13. Retrieved from https://search-ebscohostcom.login.ezproxy.library.ualberta.ca/login.aspx?direct=true \&db=lls\&AN=117625293\& $\underline{\text { site }=\text { ehost-live } \& \text { scope }=\text { site }}$

Neuendorf, K. A. (2019). 18 Content analysis and thematic analysis. In Paula Brough (Ed.), Advanced Research Methods for Applied Psychology (pp. 211-223). Routledge.

Newell, S., \& Swan, J. (1995). Professional Associations as Important Mediators of the Innovation Process. Science Communication, 16(4), 371-387. https://doi.org/10.1177/1075547095016004001

Nova Scotia Library Association. (2017, Oct 17). What can libraries do to support and promote the TRC's calls to action?. Retrieved from http://www.nsla.ns.ca/index.php/2017/10/what-can-libraries-do-to-support-and-promotethe-trcs-calls-to-action/

Nunavut Library Association. (n.d.). Our organization: Mission, vision and values. Retrieved from_ https://nunavutlibraryassociation.ca/about/organization-description/

Obille, K. L. B. (2007). An evaluation of standards for academic libraries in the Philippines. Journal of Philippine Librarianship, 27(1/2), 109-150.

Ontario Library Association. (n.d.). OBLA workplan 2017-2020. Retrieved from http://www.accessola.org/web/OLA/OLBA/About_OLBA/Strategic_Plan/OLA/OLBA/St rategic_Plan.aspx?hkey=e6c02f3d-392a-4678-9ccc-fbfc55044e47

Reyes-Escudero, V., \& Cox, J. W. (2017). Survey, Understanding, and Ethical Stewardship of Indigenous Collections: A Case Study. Collection Management, 42(3/4), 130-138. https://doi.org/10.1080/01462679.2017.1336503

Smith, L. T. (2012). Decolonizing Methodologies: Research and Indigenous Peoples (Second Edition). London, UK: Zed.

Smith, S. (2017). The creation of the CFLA/FCAB truth and reconciliation committee: The first report. Partnership: The Canadian Journal of Library and Information Practice and Research, 12(1), 1-4. https://doi.org/10.21083/partnership.v12i1.3981

Thorpe, K., \& Byrne, A. (2016). Indigenous voices in the State Library of New South Wales. Australian Library Journal, 65(1), 17-29. https://doi.org/10.1080/00049670.2016.1129682

Thorpe, K., \& Galassi, M. (2018). Diversity, inclusion \& respect: Embedding Indigenous priorities in public library services. Public Library Quarterly, 37(2), 180-194. https://doi.org/10.1080/01616846.2018.1460568

Truth and Reconciliation Commission of Canada. (2015). Honouring the Truth, Reconciling for the Future: Summary of the Final Report of the Truth and Reconciliation Commission of Canada. Retrieved from http://nctr.ca/assets/reports/Final\%20Reports/Executive_Summary_English_Web.pdf 